\title{
Multifunctional iron thiocarboxylate complexes: synthesis, reactivity and structure of $\mathrm{CpFe}(\mathrm{CO})_{2} \mathrm{SCO}-3,5-\mathrm{C}_{6} \mathrm{H}_{4}(\mathrm{COCl})_{2}$
}

\author{
Mohammad El-khateeb · Khalil J. Asali • \\ Ibrahim Jibril · Anas Abuseni · \\ Helmar Görls · Wolfgang Weigand
}

Received: 18 December 2008/ Accepted: 3 March 2009/Published online: 19 March 2009

(C) The Author(s) 2009. This article is published with open access at Springerlink.com

\begin{abstract}
A controlled substitution reaction of the chlorine atoms of 1,3,5-benzenetricarbonyl trichloride by the organoiron fragment $\left(\mathrm{CpFe}(\mathrm{CO})_{2} \mathrm{~S}\right)$ has been achieved. The complexes $\mathrm{CpFe}(\mathrm{CO})_{2} \mathrm{SCO}-3,5-\mathrm{C}_{6} \mathrm{H}_{3}(\mathrm{COCl})_{2}$ (1), 1,3-[CpFe(CO) $\left.)_{2} \mathrm{SCO}\right]_{2}-5-\mathrm{C}_{6} \mathrm{H}_{3} \mathrm{COCl}(\mathbf{2})$ and $1,3,5-[\mathrm{CpFe}$ $(\mathrm{CO})_{2} \mathrm{SCO}_{3} \mathrm{C}_{6} \mathrm{H}_{3}(3)$ were prepared from the reaction of $\left(\mu-\mathrm{S}_{x}\right)\left[\mathrm{CpFe}(\mathrm{CO})_{2}\right]_{2}(x=3,4)$ with $1,3,5-\mathrm{C}_{6} \mathrm{H}_{3}(\mathrm{COCl})_{3}$ in a 1:1, 2:1, or 3:1 metal to ligand molar ratio. The reactions of (1) with amines, thiols, and carboxylic acids produce the trifunctional mono-iron complexes $\mathrm{CpFe}(\mathrm{CO})_{2} \mathrm{SCO}-3$, 5- $\mathrm{C}_{6} \mathrm{H}_{3}(\mathrm{COY})_{2}\left[\mathrm{Y}=\mathrm{NR}_{2}(\mathbf{4}), \mathrm{SR}(\mathbf{5})\right.$, OCOR (4)]. The $\mathrm{X}$-ray structure determination of (1) is reported.
\end{abstract}

\section{Introduction}

The chemistry of ligands containing sulfur, selenium, or tellurium has been actively pursued [1-3]. These ligands have high affinity to coordinate with transition metals in inorganic and organometallic complexes [2,3]. The interest in such ligands is motivated by their bonding diversity, perspectives of reactivity, and relevance to bioinorganic chemistry [4-7].

The iron sulfide complexes $\left(\mu-\mathrm{S}_{x}\right)\left[\mathrm{CpFe}(\mathrm{CO})_{2}\right]_{2}(x=3,4)$, which are accessible through the insertion of elemental sulfur into the iron-iron bond of the dimer $\left[\mathrm{CpFe}(\mathrm{CO})_{2}\right]_{2}[8]$, were

\footnotetext{
M. El-khateeb $(\bowtie) \cdot$ K. J. Asali · A. Abuseni

Chemistry Department, Jordan University of Science

and Technology, Irbid 22110, Jordan

e-mail: kateeb@just.edu.jo

I. Jibril

Chemistry Department, Yarmouk University, Irbid, Jordan

H. Görls · W. Weigand

Institut für Anorganische Chemie, Friedrich-Schiller-Universtät

Jena, August-Bebel Strasse 2, Jena 07743, Germany
}

found to be reactive toward electrophiles. Their reactions with mono-functional electrophiles such as acid chlorides [9, 10], sulfonyl chlorides [11], chloroformates [12], chlorothioformates [13], chlorodithioformates [14], and $O$-alkyloxalyl chlorides [15] produced the complexes $\mathrm{CpFe}(\mathrm{CO})_{2} \mathrm{SZ}(\mathrm{Z}=$ $\left.\mathrm{COR}, \mathrm{SO}_{2} \mathrm{R}, \mathrm{CO}_{2} \mathrm{R}, \mathrm{C}(\mathrm{S}) \mathrm{OR}, \mathrm{CS}_{2} \mathrm{R}, \mathrm{COCO}_{2} \mathrm{R}\right)$ which contain one iron centre. The reaction of these iron sulfides with bifunctional acid chlorides, such as oxalyl chloride, gave [ $\mathrm{CpFe}$ $(\mathrm{CO})_{2} \mathrm{SCO}_{2}$ which contains two iron atoms [15]. On the other hand, their reaction with terephthaloyl chloride gave either the di-iron thioterephthalates $\left[\mathrm{CpFe}(\mathrm{CO})_{2} \mathrm{SCO}\right]_{2}\left(4-\mathrm{C}_{6} \mathrm{H}_{4}\right)$ or the mono-iron complex $\mathrm{CpFe}(\mathrm{CO})_{2} \mathrm{SCO}-4-\mathrm{C}_{6} \mathrm{H}_{4} \mathrm{COCl}$, depending on the molar ratio of the reactants [16]. The latter complex was found to be reactive toward amines, phenols, carboxylic acids, and thiols to produce the bi-functional products $\mathrm{CpFe}(\mathrm{CO})_{2} \mathrm{ECO}-4-\mathrm{C}_{6} \mathrm{H}_{4} \mathrm{COY}\left(\mathrm{Y}=\mathrm{NR}_{2}\right.$, OR, OCOR, SR) [16-19]. The dimeric complexes containing two iron atoms with either homo- or hetero-bis(chalcogeno)-ligands were prepared by the reactions of $\mathrm{CpFe}(\mathrm{CO})_{2} \mathrm{SCO}-4$ $\mathrm{C}_{6} \mathrm{H}_{4} \mathrm{COCl}$ with the iron chalcogenides $\left(\mu-\mathrm{E}_{x}\right)\left[\mathrm{CpFe}(\mathrm{CO})_{2}\right]_{2}$ $(\mathrm{E}=\mathrm{S}, \mathrm{Se})[18,19]$.

In this article, we describe the reaction of the iron sulfides $\left(\mu-\mathrm{S}_{x}\right)\left[\mathrm{CpFe}(\mathrm{CO})_{2}\right]_{2}$ with 1,3,5-benzenetricarbonyl trichloride, which contains three acid chloride groups as an extension to our efforts in this area. The reactions of the mono-iron complex $\mathrm{CpFe}(\mathrm{CO})_{2} \mathrm{SCO}-3,5-\mathrm{C}_{6} \mathrm{H}_{3}(\mathrm{COCl})_{2}$ with amines, thiols, or carboxylic acids are discussed.

\section{Experimental}

General considerations

All reactions and manipulations were carried out under a dinitrogon atmosphere by using standard Schlenk line 
techniques. The use of dry solvents is necessary. The starting materials $\left(\mu-\mathrm{S}_{x}\right)\left[\mathrm{CpFe}(\mathrm{CO})_{2}\right]_{2} \quad(x=3,4)$ were prepared according to the literature method [8], while $1,3,5-\mathrm{C}_{6} \mathrm{H}_{3}(\mathrm{COCl})_{3}$, amines, thiols, and carboxylic acids were obtained commercially (Acros) and were used without further purification. Infrared (i.r.) spectra were recorded on a Nicolet-Impact 410 FT-IR spectrometer. ${ }^{1} \mathrm{H}$-NMR spectra were recorded on a Bruker-Avance- $400 \mathrm{MHz}$ spectrometer. Chemical shifts are given in ppm relative to TMS at $0 \mathrm{ppm}$. Elemental analyses were carried out on a Perkin-Elmer 2400 Series II CHN-analyzer.

\section{Preparation of $\mathrm{CpFe}(\mathrm{CO})_{2} \mathrm{SCO}-3,5-\mathrm{C}_{6} \mathrm{H}_{3}(\mathrm{COCl})_{2}(\mathbf{1})$}

A solution of $\left(\mu-\mathrm{S}_{x}\right)\left[\mathrm{CpFe}(\mathrm{CO})_{2}\right]_{2}(x=3,4)(2.00 \mathrm{mmol})$ in diethyl ether $\left(50 \mathrm{~cm}^{3}\right)$ was dropwise added, over a period of $30 \mathrm{~min}$, to a solution of $1,3,5-\mathrm{C}_{6} \mathrm{H}_{3}(\mathrm{COCl})_{3}$ $(0.67 \mathrm{~g}, 2.5 \mathrm{mmol})$ in diethyl ether $\left(10 \mathrm{~cm}^{3}\right)$. The resulting mixture was stirred for $2 \mathrm{~h}$ at room temperature. The volatiles were removed under vacuum and re-dissolved in a minimum amount of $\mathrm{CH}_{2} \mathrm{Cl}_{2}$. This solution was introduced to a silica gel column made up in hexane. Elution with a mixture of diethyl ether and hexane (7:3 volume ratio) gave an orange band which was collected and identified as $\mathrm{CpFe}(\mathrm{CO})_{2} \mathrm{SCO}-3,5-\mathrm{C}_{6} \mathrm{H}_{3}(\mathrm{COCl})_{2}$, followed by a red band which was identified as $\mathrm{CpFe}(\mathrm{CO})_{2} \mathrm{Cl}$. The title complex was re-crystallized from $\mathrm{CH}_{2} \mathrm{Cl}_{2} /$ hexane. Yield $=0.54 \mathrm{~g}$, $62 \%$. M.p $=193-195{ }^{\circ}$ C. I.r. $\left(\mathrm{CH}_{2} \mathrm{Cl}_{2}, \mathrm{~cm}^{-1}\right): v_{\mathrm{C} \equiv \mathrm{O}}=$ 2047 (vs); 2003 (vs); $v_{\mathrm{C}=\mathrm{O}}=1764$ (s); $v_{\mathrm{SC}=\mathrm{O}}=1612$ (m). ${ }^{1} \mathrm{H}-\mathrm{NMR}\left(\mathrm{CDCl}_{3}\right): \delta 9.10\left(\mathrm{~d}, 2 \mathrm{H}, \mathrm{H}_{\mathrm{a}}\right) ; 8.84\left(\mathrm{t}, 1 \mathrm{H}, \mathrm{H}_{\mathrm{b}}\right)$; 5.09 (s, $5 \mathrm{H}, \mathrm{Cp}$ ). $\mathrm{C}_{16} \mathrm{H}_{8} \mathrm{FeO}_{5} \mathrm{SCl}_{2}$ calcd.: $\mathrm{C}, 43.8 ; \mathrm{H}, 1.8 ; \mathrm{S}$, 7.3\%. Found: C, 43.4; H, 2.1; S, 6.9\%.

\section{Preparation of $1,3-\left[\mathrm{CpFe}(\mathrm{CO})_{2} \mathrm{SCO}\right]_{2}-5-\mathrm{C}_{6} \mathrm{H}_{3} \mathrm{COCl}(2)$}

A solution of $1,3,5-\mathrm{C}_{6} \mathrm{H}_{3}(\mathrm{COCl})_{3}(0.26 \mathrm{~g}, 1 \mathrm{mmol})$ in diethyl ether $\left(150 \mathrm{~cm}^{3}\right)$ was added to a solution $(2.00 \mathrm{mmol})$ of $\left(\mu-\mathrm{S}_{x}\right)\left[\mathrm{CpFe}(\mathrm{CO})_{2}\right]_{2}(x=3,4)(2.00 \mathrm{mmol})$ in diethyl ether $\left(50 \mathrm{~cm}^{3}\right)$ under dinitrogen atmosphere. The resulting mixture was stirred for $3 \mathrm{~h}$ at room temperature. The volatiles were removed under vacuum and re-dissolved in a minimum amount of $\mathrm{CH}_{2} \mathrm{Cl}_{2}$. This solution was introduced to a silica gel column made up in hexane. Elution with THF/ hexane gave an orange band which was discarded. Elution with THF gave an orange band which was collected and identified as $1,3-\left[\mathrm{CpFe}(\mathrm{CO})_{2} \mathrm{SCO}\right]_{2}-5-\mathrm{C}_{6} \mathrm{H}_{3} \mathrm{COCl}$ and was re-crystallized from $\mathrm{CH}_{2} \mathrm{Cl}_{2} /$ hexane. Yield $=0.17 \mathrm{~g}, 29 \%$. M.p $=213-214{ }^{\circ} \mathrm{C}$. I.r. $\left(\mathrm{CH}_{2} \mathrm{Cl}_{2}, \mathrm{~cm}^{-1}\right): v_{\mathrm{C} \equiv \mathrm{O}}=2046$ (vs); $2001(\mathrm{vs}), v_{\mathrm{C}=\mathrm{O}}=1761(\mathrm{w}) ; v_{\mathrm{SC}=\mathrm{O}}=1610(\mathrm{~m}) .{ }^{1} \mathrm{H}-$ $\operatorname{NMR}\left(\mathrm{CDCl}_{3}\right): \delta 9.18\left(\mathrm{bs}, 1 \mathrm{H}, \mathrm{H}_{\mathrm{a}}\right) ; 8.86\left(\mathrm{bs}, 2 \mathrm{H}, \mathrm{H}_{\mathrm{b}}\right) ; 5.06$ (s, $10 \mathrm{H}, \mathrm{Cp}$ ). $\mathrm{C}_{23} \mathrm{H}_{13} \mathrm{Fe}_{2} \mathrm{O}_{7} \mathrm{~S}_{2} \mathrm{Cl}$ calcd.: C, 45.1; H, 2.1; S, 10.5\%. Found: C, 44.9; H, 2.0; S, 9.8\%.
Preparation of $1,3,5-\left[\mathrm{CpFe}(\mathrm{CO})_{2} \mathrm{SCO}\right]_{3} \mathrm{C}_{6} \mathrm{H}_{3}(\mathbf{3})$

A solution of $1,3,5-\mathrm{C}_{6} \mathrm{H}_{3}(\mathrm{COCl})_{3}(0.18 \mathrm{~g}, 0.67 \mathrm{mmol})$ in diethyl ether $\left(100 \mathrm{~cm}^{3}\right)$ was added slowly over a period of $1 \mathrm{~h}$ to a solution of $\left(\mu-\mathrm{S}_{x}\right)\left[\mathrm{CpFe}(\mathrm{CO})_{2}\right]_{2} \quad(2.00 \mathrm{mmol})$ $(x=3,4)$ in diethyl ether $\left(50 \mathrm{~cm}^{3}\right)$ under dinitrogen atmosphere. The resulting mixture was stirred for $3 \mathrm{~h}$ at room temperature. The volatiles were removed under vacuum and re-dissolved in a minimum amount of $\mathrm{CH}_{2} \mathrm{Cl}_{2}$. This solution was introduced to a silica gel column made up in hexane. Elution with 1:1 volume ratio of THF/hexane gave an orange band, which was discarded. Elution with THF gave an orange band which was collected and recrystallized from $\mathrm{CH}_{2} \mathrm{Cl}_{2} /$ hexane. Yield $=0.24 \mathrm{~g}, 48 \%$. M.p $=227$ $228{ }^{\circ}$ C. I.r. $\left(\mathrm{CH}_{2} \mathrm{Cl}_{2}, \mathrm{~cm}^{-1}\right): v_{\mathrm{C} \equiv \mathrm{O}}=2044$ (vs); 2000 (vs), $v_{\mathrm{SC}=\mathrm{O}}=1606(\mathrm{~m}) .{ }^{1} \mathrm{H}-\mathrm{NMR}\left(\mathrm{CDCl}_{3}\right): \delta 8.91(\mathrm{~s}, 3 \mathrm{H}, \mathrm{Ar}-\mathrm{H})$; 5.03 (s, $15 \mathrm{H}, \mathrm{Cp}$ ). $\mathrm{C}_{30} \mathrm{H}_{18} \mathrm{Fe}_{3} \mathrm{O}_{9} \mathrm{~S}_{3}$ calcd.: $\mathrm{C}, 45.8 ; \mathrm{H}, 2.3 ; \mathrm{S}$, $12.2 \%$. Found: C, $45.3 ; \mathrm{H}, 2.3 ; \mathrm{S}, 12.4 \%$.

\section{Preparation of $\mathrm{CpFe}(\mathrm{CO})_{2} \mathrm{SCO}-3,5-\mathrm{C}_{6} \mathrm{H}_{3}\left(\mathrm{CONR}^{1} \mathrm{R}^{2}\right)_{2}$} (4)

A THF solution $\left(60 \mathrm{~cm}^{3}\right)$ containing the amine $(2.3 \mathrm{mmol})$ and (1) $(0.5 \mathrm{~g}, 1.14 \mathrm{mmol})$ was refluxed. The volatiles were removed under vacuum and the residue was re-dissolved in $\mathrm{CH}_{2} \mathrm{Cl}_{2}$ and transferred to a chromatographic column made up in hexane. An orange band was elueted with $\mathrm{CH}_{2} \mathrm{Cl}_{2}$ /diethyl ether (9:1 volume ratio). This band was collected and identified as $\mathrm{CpFe}(\mathrm{CO})_{2} \mathrm{SCO}-3,5-\mathrm{C}_{6} \mathrm{H}_{3}$ $\left(\mathrm{CONR}^{1} \mathrm{R}^{2}\right)_{2}$ and re-crystallized from $\mathrm{CH}_{2} \mathrm{Cl}_{2}$ /hexane.

\section{$\mathrm{CpFe}(\mathrm{CO})_{2} \mathrm{SCO}-3,5-\mathrm{C}_{6} \mathrm{H}_{3}(\mathrm{CONHPh})_{2}(\mathbf{4 a})$}

Yield $=0.42$ g, 67\%. M.p $=220-221{ }^{\circ} \mathrm{C}$. Reflux time $=$ 2 h. I.r. $\left(\mathrm{KBr}, \mathrm{cm}^{-1}\right): v_{\mathrm{C} \equiv \mathrm{O}}=2036$ (vs); 1987 (v), $v_{\mathrm{NC}=\mathrm{O}}=1647(\mathrm{~s}) ; v_{\mathrm{SC}=\mathrm{O}}=1601(\mathrm{~m}) .{ }^{1} \mathrm{H}-\mathrm{NMR}\left(\mathrm{CDCl}_{3}\right)$ : $\delta 8.63\left(\mathrm{~s}, 2 \mathrm{H}, \mathrm{H}_{\mathrm{a}}\right) ; 8.39\left(\mathrm{~s}, 1 \mathrm{H}, \mathrm{H}_{\mathrm{b}}\right) ; 8.29(\mathrm{bs}, 2 \mathrm{H}, \mathrm{NH}) ; 7.70$ (d, 4H, Ar-H); 7.37 (t, 4H, Ar-H); 7.16 (t, 2H, Ar-H), 5.00 (s, 5H, Cp). $\mathrm{C}_{28} \mathrm{H}_{21} \mathrm{FeO}_{5} \mathrm{SN}_{2} \cdot 2 \mathrm{CH}_{2} \mathrm{Cl}_{2}$ calcd.: C, 54.6; $\mathrm{H}, 3.5 ; \mathrm{S}, 5.0 ; \mathrm{N}, 4.4 \%$. Found: $\mathrm{C}, 54.2 ; \mathrm{H}, 3.5 ; \mathrm{S}, 4.7$; $\mathrm{N}, 4.3 \%$.

$\mathrm{CpFe}(\mathrm{CO})_{2} \mathrm{SCO}-3,5-\mathrm{C}_{6} \mathrm{H}_{3}\left(\mathrm{CON}\left(\mathrm{CH}_{3}\right) \mathrm{Ph}\right)_{2}(\mathbf{4 b})$

Yield $=0.37$ g, 56\%. M.p $=180-181{ }^{\circ} \mathrm{C}$. Reflux time $=$ 3 h. I.r. $\left(\mathrm{KBr}, \mathrm{cm}^{-1}\right): v_{\mathrm{C} \equiv \mathrm{O}}=2041$ (vs); 1991 (vs), $v_{\mathrm{NC}=\mathrm{O}}=1648(\mathrm{~s}) ; v_{\mathrm{SC}=\mathrm{O}}=1601(\mathrm{~m}) .{ }^{1} \mathrm{H}-\mathrm{NMR}\left(\mathrm{CDCl}_{3}\right)$ : $\delta 7.91$ (bs, $2 \mathrm{H}, \mathrm{H}_{\mathrm{a}}$ ); 7.29 (bs, $1 \mathrm{H}, \mathrm{H}_{\mathrm{b}}$ ); 7.19 (t, $\left.4 \mathrm{H}, \mathrm{Ph}\right) ; 7.11$ (t, 2H, Ph); $6.88(\mathrm{~d}, 4 \mathrm{H}, \mathrm{Ph}) ; 4.98$ (s, 5H, Cp); 3.38 (s, 6H, $\mathrm{CH}_{3}$ ). $\mathrm{C}_{28} \mathrm{H}_{24} \mathrm{FeO}_{5} \mathrm{SN}_{2} .0 .5 \mathrm{CH}_{2} \mathrm{Cl}_{2}$ calcd.: $\mathrm{C}, 58.8 ; \mathrm{H}, 4.1$; S, 5.2; N, 4.5\%. Found: C, 58.4; H, 3.9; S, 4.9; N, 4.4\%. 
$\mathrm{CpFe}(\mathrm{CO})_{2} \mathrm{SCO}-3,5-\mathrm{C}_{6} \mathrm{H}_{3}\left(\mathrm{CON}\left(\mathrm{CH}_{3}\right) \mathrm{CH}_{2} \mathrm{Ph}\right)_{2}(4 \mathrm{c})$

Yield $=0.52 \mathrm{~g}, 75 \%$. M.p $=118-120{ }^{\circ} \mathrm{C}$. Reflux time $=$ 3 h. I.r. $\left(\mathrm{KBr}, \mathrm{cm}^{-1}\right): v_{\mathrm{C} \equiv \mathrm{O}}=2038$ (vs); 1985 (vs), $v_{\mathrm{NC}=\mathrm{O}}=1648(\mathrm{~s}) ; v_{\mathrm{SC}=\mathrm{O}}=1590(\mathrm{~m}) .{ }^{1} \mathrm{H}-\mathrm{NMR}\left(\mathrm{CDCl}_{3}\right)$ : $\delta 8.25\left(\mathrm{~s}, 2 \mathrm{H}, \mathrm{H}_{\mathrm{a}}\right) ; 7.65\left(\mathrm{~s}, 1 \mathrm{H}, \mathrm{H}_{\mathrm{b}}\right) ; 7.36(\mathrm{~m}, 8 \mathrm{H}, \mathrm{Ph}) ; 7.14$ (m, 2H, Ph); 5.05 (s, 5H, Cp); $4.51\left(\mathrm{~s}, 4 \mathrm{H}, \mathrm{CH}_{2}\right) ; 3.03$ (s, $\left.6 \mathrm{H}, \mathrm{CH}_{3}\right) . \mathrm{C}_{32} \mathrm{H}_{28} \mathrm{FeO}_{5} \mathrm{SN}_{2} .0 .5 \mathrm{CH}_{2} \mathrm{Cl}_{2}$ calcd.: $\mathrm{C}, 60.0 ; \mathrm{H}$, $4.5 ; \mathrm{S}, 4.9 ; \mathrm{N}, 4.3 \%$ Found: C, 59.6; H, 4.3; S, 4.7; N, $3.9 \%$.

Preparation of $\mathrm{CpFe}(\mathrm{CO})_{2} \mathrm{SCO}-3,5-\mathrm{C}_{6} \mathrm{H}_{3}(\mathrm{COSR})_{2}$ (5)

A THF solution $\left(50 \mathrm{~cm}^{3}\right)$ containing $2.50 \mathrm{mmol}$ of thiol and (1) $(0.50 \mathrm{~g}, 1.14 \mathrm{mmol})$ was refluxed for $6 \mathrm{~h}$. The solvent was removed under vacuum and the residue was redissolved in a minimum amount of $\mathrm{CH}_{2} \mathrm{Cl}_{2}$ and transferred to a silica gel column made up in hexane. An orange band was eluted by a mixture of $\mathrm{CH}_{2} \mathrm{Cl}_{2}$ /diethylether (6:4 volume ratio). The collected products were recrystallized from $\mathrm{CH}_{2} \mathrm{Cl}_{2}$ /hexane.

\section{$\mathrm{CpFe}(\mathrm{CO})_{2} \mathrm{SCO}-3,5-\mathrm{C}_{6} \mathrm{H}_{3}(\mathrm{COSR})_{2}$ (5a)}

Yield $=0.53$ g, 77\%. M.p $=152-153{ }^{\circ} \mathrm{C}$. I.r. $\left(\mathrm{KBr}, \mathrm{cm}^{-1}\right)$ : $v_{\mathrm{C} \equiv \mathrm{O}}=2040(\mathrm{vs}) ; 1991(\mathrm{vs}), v_{\mathrm{C}=\mathrm{O}}=1661(\mathrm{~s}) ; v_{\mathrm{SC}=\mathrm{O}}=$ $1611(\mathrm{~m}) .{ }^{1} \mathrm{H}-\mathrm{NMR}\left(\mathrm{CDCl}_{3}\right): \delta 9.01\left(\mathrm{~d}, 2 \mathrm{H}, \mathrm{H}_{\mathrm{a}}\right) ; 8.67(\mathrm{t}, 1 \mathrm{H}$, $\mathrm{H}_{\mathrm{b}}$ ); 7.56 (m, 4H, Ph); 7.45 (m, 6H, Ph); 5.13 (s, 5H, Cp). $\mathrm{C}_{28} \mathrm{H}_{18} \mathrm{FeO}_{5} \mathrm{~S}_{3} .0 .5 \mathrm{CH}_{2} \mathrm{Cl}_{2}$ calcd.: C, 54.4; H, 3.0; S, $15.3 \%$. Found: C, 54.4; H, 2.9; S, 14.6\%.

\section{$\mathrm{CpFe}(\mathrm{CO})_{2} \mathrm{SCO}-3,5-\mathrm{C}_{6} \mathrm{H}_{3}\left(\mathrm{COSCH}_{2} \mathrm{Ph}\right)_{2}(\mathbf{5 b})$}

Yield $=0.62$ g, 89\%. M.p $=139-141{ }^{\circ}$ C. I.r. $\left(\mathrm{KBr}, \mathrm{cm}^{-1}\right)$ : $v_{\mathrm{C} \equiv \mathrm{O}}=2038$ (vs); $1987(\mathrm{vs}), v_{\mathrm{C}=\mathrm{O}}=1658(\mathrm{~s}) ; v_{\mathrm{SC}=\mathrm{O}}=$ $1608(\mathrm{~m}) .{ }^{1} \mathrm{H}-\mathrm{NMR}\left(\mathrm{CDCl}_{3}\right): \delta 8.91\left(\mathrm{~d}, 2 \mathrm{H}, \mathrm{H}_{\mathrm{a}}\right) ; 8.72(\mathrm{t}, 1 \mathrm{H}$, $\mathrm{H}_{\mathrm{b}}$ ); 7.37-7.53 (m, 10H, Ph); 5.08 (s, 5H, Cp); 4.36 (s, 4H, $\mathrm{CH}_{2}$ ). $\mathrm{C}_{30} \mathrm{H}_{22} \mathrm{FeO}_{5} \mathrm{~S}_{3} \cdot 0.5 \mathrm{CH}_{2} \mathrm{Cl}_{2}$ calcd.: $\mathrm{C}, 55.7 ; \mathrm{H}, 3.5 ; \mathrm{S}$, $14.6 \%$. Found: C, 55.2; H, 3.4; S, $13.8 \%$.

\section{Preparation of $\mathrm{CpFe}(\mathrm{CO})_{2} \mathrm{SCO}-3,5-\mathrm{C}_{6} \mathrm{H}_{3}\left(\mathrm{C}_{2} \mathrm{O}_{3} \mathrm{R}\right)_{2}(\mathbf{6})$}

A THF solution $\left(50 \mathrm{~cm}^{3}\right)$ containing $2.60 \mathrm{mmol}$ of carboxylic acid and (1) (0.50 g, $1.14 \mathrm{mmol})$ was refluxed for $12 \mathrm{~h}$. The solvent was removed under vacuum and the residue was re-dissolved in a minimum amount of THF and transferred to a silica gel column made up in hexane. An orange band was eluted by a mixture of THF/hexane $(8: 2$ volume ratio), the collected products were re-crystallized from $\mathrm{THF} /$ hexane.
$\mathrm{CpFe}(\mathrm{CO})_{2} \mathrm{SCO}-3,5-\mathrm{C}_{6} \mathrm{H}_{3}\left(\mathrm{C}_{2} \mathrm{O}_{3} \mathrm{CF}_{3}\right)_{2}$ (6a)

Yield $=0.38$ g, 56\%. M.p $=176-178{ }^{\circ}$ C. I.r. $\left(\mathrm{KBr}, \mathrm{cm}^{-1}\right)$ : $v_{\mathrm{C} \equiv \mathrm{O}}=2037(\mathrm{vs}) ; 1996(\mathrm{vs}), v_{\mathrm{C}=\mathrm{O}}=1728(\mathrm{~s}) ; 1696(\mathrm{~s}) ;$ $v_{\mathrm{SC}=\mathrm{O}}=1608(\mathrm{~m}) .{ }^{1} \mathrm{H}-\mathrm{NMR}$ (Acetone- $\left.d_{6}\right): \delta 8.95(\mathrm{~d}, 2 \mathrm{H}$, $\mathrm{H}_{\mathrm{a}}$ ); $8.77\left(\mathrm{t}, 1 \mathrm{H}, \mathrm{H}_{\mathrm{b}}\right.$ ); 5.34 (s, $\left.5 \mathrm{H}, \mathrm{Cp}\right) . \mathrm{C}_{20} \mathrm{H}_{8} \mathrm{FeO}_{9} \mathrm{SF}_{6} .2 \mathrm{THF}$ calcd.: C, 45.0; H, 3.3; S, 4.3\%. Found: C, 44.9; H, 3.2; S, $4.1 \%$.

$\mathrm{CpFe}(\mathrm{CO})_{2} \mathrm{SCO}-3,5-\mathrm{C}_{6} \mathrm{H}_{3}\left(\mathrm{C}_{2} \mathrm{O}_{3} \mathrm{CCl}_{3}\right)_{2}(\mathbf{6 b})$

Yield $=0.31 \mathrm{~g}, \quad 39 \% . \quad$ M.p $=187-189^{\circ} \mathrm{C} . \quad$ I.r. $\quad(\mathrm{KBr}$, $\left.\mathrm{cm}^{-1}\right): v_{\mathrm{C} \equiv \mathrm{O}}=2036(\mathrm{vs}) ; 1995$ (vs), $v_{\mathrm{C}=\mathrm{O}}=1728(\mathrm{~s})$; $1697(\mathrm{~s}) ; v_{\mathrm{SC}=\mathrm{O}}=1607(\mathrm{~m}) .{ }^{1} \mathrm{H}-\mathrm{NMR}$ (Acetone- $\left.d_{6}\right): \delta$ $8.94\left(\mathrm{~d}, 2 \mathrm{H}, \mathrm{H}_{\mathrm{a}}\right) ; 8.75\left(\mathrm{t}, 1 \mathrm{H}, \mathrm{H}_{\mathrm{b}}\right) ; 5.33(\mathrm{~s}, 5 \mathrm{H}, \mathrm{Cp})$. $\mathrm{C}_{20} \mathrm{H}_{8} \mathrm{FeO}_{9} \mathrm{SCl}_{6}$.2THF calcd.: $\mathrm{C}, 40.2 ; \mathrm{H}, 2.9 ; \mathrm{S}, 3.8 \%$. Found: C, 40.0; H, 2.8; S, 3.6\%.

Crystallographic analysis of $\mathrm{CpFe}(\mathrm{CO})_{2} \mathrm{SCO}-3$, $5-\mathrm{C}_{6} \mathrm{H}_{3}(\mathrm{COCl})_{2}$, (1)

A single crystal suitable for X-ray structure determination of (1) was obtained by recrystallization from $\mathrm{CH}_{2} \mathrm{Cl}_{2}$ /hexane mixture. Crystallographic data were as follows: $\mathrm{C}_{16} \mathrm{H}_{8} \mathrm{Cl}_{2}$ $\mathrm{FeO}_{5} \mathrm{~S}$, formula weight: 439.03 , space group $\mathrm{P} 2(1) / \mathrm{n}$ with $a=6.9492(4) \AA, \quad b=20.7699(14) \AA, \quad c=11.9657 \AA$, $\beta=102.280^{\circ}, V=1687.45(16) \AA^{3}, \rho_{\text {calc }}=1.728 \mathrm{~g} / \mathrm{cm}^{3}$ and $Z=4$. The measurements were collected at 183(2) K on a Kappa CCD diffractometer with a graphite monochromator $(\lambda=0.71073 \AA)$. There were 11154 independent reflections with 3834 observed reflections $(>2 \sigma(\mathrm{I}))$. The structure was solved by direct methods using SHELXS97 (Sheldrick, 1997) [20] and difmap synthesis using SHELXTL96 (Sheldrick, 1996) [21]. All non-hydrogen atoms were fully refined with anisotropic thermal parameters. The refinement coverage to $R 1=0.0635$ and $w R 2=0.1527$.

\section{Results and discussion}

Synthesis and characterization

The reaction of $\left(\mu-\mathrm{S}_{x}\right)\left[\mathrm{CpFe}(\mathrm{CO})_{2}\right]_{2}$ with the trifunctional acid chloride $1,3,5-\mathrm{C}_{6} \mathrm{H}_{3}(\mathrm{COCl})_{3}$ can be controlled to give either the mono-, bi- or tri-iron complexes shown in Scheme 1. The organo-iron chloride, $\mathrm{CpFe}(\mathrm{CO})_{2} \mathrm{Cl}$ was obtained as a byproduct of these reactions, separated from the products by column chromatography and identified.

Complexes (1), (2), and (3) are stable as solids and are also stable in solution. The structures of these complexes were identified by spectroscopic techniques (i.r. and $\left.{ }^{1} \mathrm{H}-\mathrm{NMR}\right)$ as well as by elemental analysis. Their i.r. spectra show 2 bands for the terminal carbonyl groups in 


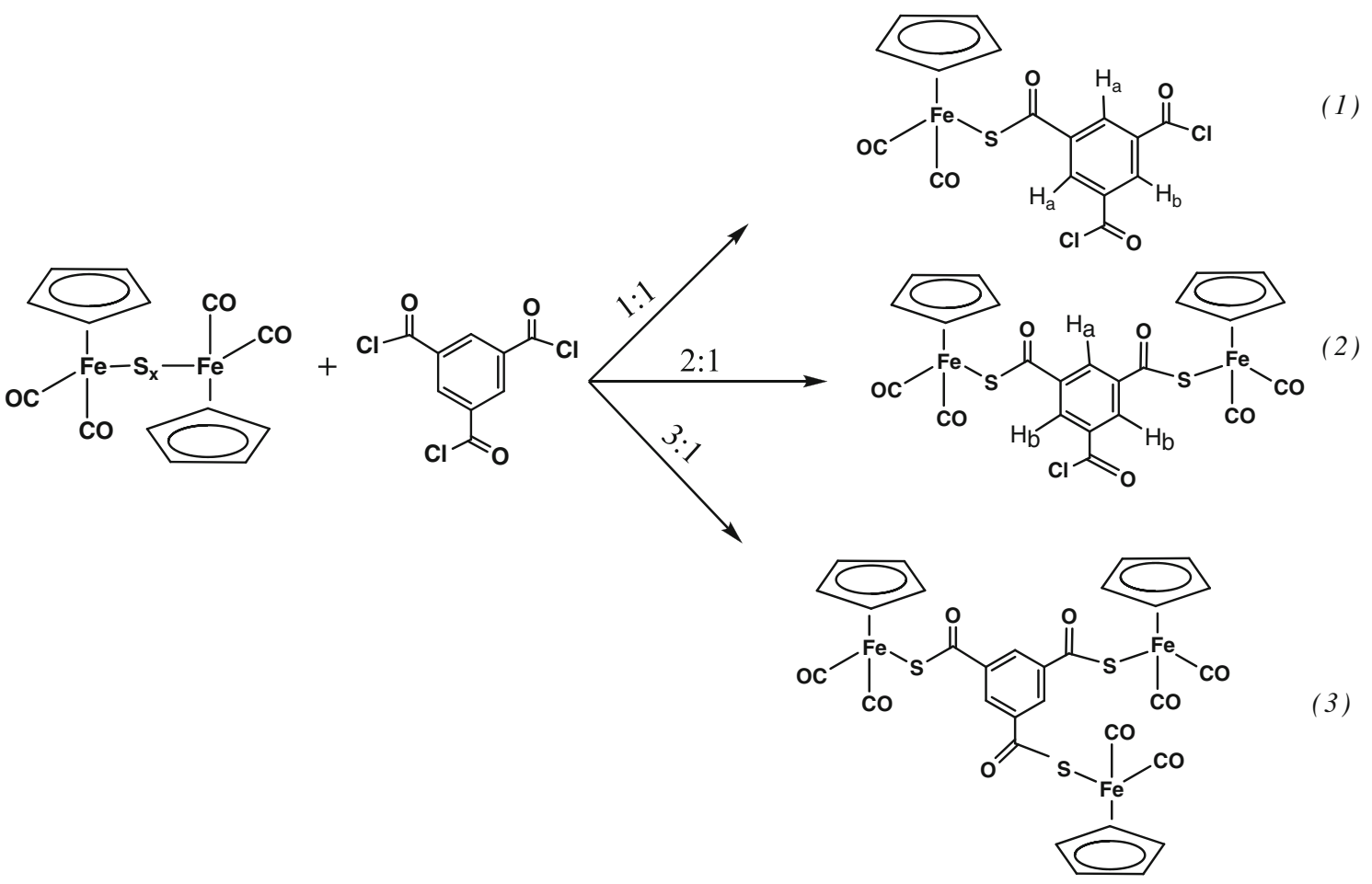

Scheme 1 Preparation of $\mathrm{CpFe}(\mathrm{CO})_{2} \mathrm{SCO}-3,5-\mathrm{C}_{6} \mathrm{H}_{3}(\mathrm{COCl})_{2}(\mathbf{1})$, $\left[\mathrm{CpFe}(\mathrm{CO})_{2} \mathrm{SCO}\right]_{2}-5-\mathrm{C}_{6} \mathrm{H}_{3} \mathrm{COCl}(\mathbf{2})$ and $1,3,5-\left[\mathrm{CpFe}(\mathrm{CO})_{2} \mathrm{SCO}\right]_{3}(3)$

the ranges of 2047-2044 and 2003-2000 $\mathrm{cm}^{-1}$, which are comparable to those reported for the corresponding thiocarboxylates $\mathrm{CpFe}(\mathrm{CO})_{2} \mathrm{SCOR}[9,10]$. The bands are shifted to lower wave-numbers as the number of the iron fragment increases, consistent with increasing electron density around the metal centre. The spectra show also a medium band in the range of $1606-1612 \mathrm{~cm}^{-1}$ for the thiocarboxylate-carbonyl group. For (1) and (2) the presence of the acid chloride group is confirmed by the presence a band at $1764-1761 \mathrm{~cm}^{-1}$ [16]. The ${ }^{1} \mathrm{H}-\mathrm{NMR}$ spectra of (1)-(3) exhibit a singlet in the range of 5.03$5.09 \mathrm{ppm}$ for the Cp-protons. This chemical shift range is similar to that observed for the thiocarboxylate (4.98$5.13 \mathrm{ppm})[9,10]$ and thiocarbonate $(4.98-5.12 \mathrm{ppm})$ analogues [12]. The protons of the phenyl ring appear as two sets for (1) (doublet and triplet) and for (2) (two broad singlets) and as one singlet for (3).

Complex (1) was reacted with amines, thiols, and carboxylic acids to give the substituted complexes $\mathrm{CpFe}(\mathrm{CO})_{2^{-}}$ SCO-3,5- $\mathrm{C}_{6} \mathrm{H}_{3}\left(\mathrm{CONR}^{1} \mathrm{R}^{2}\right)_{2}(4), \mathrm{CpFe}(\mathrm{CO})_{2} \mathrm{SCO}-3,5-\mathrm{C}_{6} \mathrm{H}_{3}$ $(\mathrm{COSR})_{2}(\mathbf{5})$, or $\mathrm{CpFe}(\mathrm{CO})_{2} \mathrm{SCO}-3,5-\mathrm{C}_{6} \mathrm{H}_{3}\left(\mathrm{CO}_{2} \mathrm{COR}\right)_{2}(\mathbf{6})$ respectively as shown in Scheme 2.

Compounds (4), (5), and (6) were characterized by i.r., ${ }^{1} \mathrm{H}-\mathrm{NMR}$ spectroscopy and elemental analysis. The i.r. spectra of each of these complexes exhibit two strong bands in the ranges of $2040-2036 \mathrm{~cm}^{-1}$ and $1996-$ $1985 \mathrm{~cm}^{-1}$ for the terminal carbonyl group coordinated to the iron centre. These ranges are shifted to lower wave- numbers compared to the starting complex (1). The spectra contain a medium band in the range of $1611-1590 \mathrm{~cm}^{-1}$ for the thiocarboxylate-carbonyl ligands. Additionally, the carbonyl group of the amide or thio-ester groups appears as a medium band in the ranges of $1647-1680 \mathrm{~cm}^{-1}$ or 1608 $1611 \mathrm{~cm}^{-1}$, respectively. The corresponding carboxylato ligands show two bands in the range of 1697-1696 and at $1728 \mathrm{~cm}^{-1}$. These ranges are found in accordance to the electronegativity of the $N\left(R^{1}\right) R^{2}$, SR or OCOR groups. ${ }^{1} \mathrm{H}-\mathrm{NMR}$ spectra of (4), (5), and (6) show singlet peak in the range of 4.90-5.34 ppm for the cyclopentadienyl protons and the expected patterns of the aromatic protons.

\section{Crystal structure of (1)}

The molecular structure of $\mathrm{CpFe}(\mathrm{CO})_{2} \mathrm{SCO}-3,5-\mathrm{C}_{6} \mathrm{H}_{3}(\mathrm{COCl})_{2}$ (1) is shown in Fig. 1. Selected bond distances and the bond angles of (1) are shown in Table 1. The structure of (1) is a typical piano stool with three legs in which the cyclopentadinyl ligand is bonded to iron in an $\eta^{5}$-fashion. The $\mathrm{Fe}-\mathrm{C}(\mathrm{Cp}) \quad$ (average $=2.093 \AA$ ) and $\mathrm{Fe}-\mathrm{C}(\mathrm{CO})$ (1.764(7), 1.786(6) $⿱$ ) bond lengths of (1) are similar to those found in $\mathrm{CpFe}(\mathrm{CO})_{2}$-containing complexes [8-14]. The $\mathrm{Fe}-\mathrm{S}$ bond distance in (1) of 2.2529(14) $\AA$ is comparable to that found in $\mathrm{CpFe}(\mathrm{CO})_{2} \mathrm{SX}$ complexes $\left[\mathrm{X}=\mathrm{SO}_{2} \mathrm{CCl}_{3}\right.$ (2.2803(13) $\AA$ ), $\mathrm{CO}_{2} \mathrm{Et}(2.2675(10) \AA), \mathrm{CO}-2-\mathrm{C}_{6} \mathrm{H}_{4} \mathrm{NO}_{2}$ (2.266(1) $\AA$ ), $\mathrm{C}(\mathrm{S}) \mathrm{O}-\mathrm{C}_{6} \mathrm{H}_{4} \mathrm{Cl}(2.2765(5) \AA)$ ] [9-12]. The $\mathrm{C}-\mathrm{O}$ bond lengths of the ketonic carbonyl group of the 
Scheme 2 Reactions of $\mathrm{CpFe}(\mathrm{CO})_{2} \mathrm{SCO}-3,5-$

$\mathrm{C}_{6} \mathrm{H}_{3}(\mathrm{COCl})_{2}(\mathbf{1})$ with amines, thiols or carboxylic acids<smiles>Cc1c(C(=O)Cl)cc(C(=O)SP(=O)([O-])c2ccccc2)c(C)c1C(=O)Cl</smiles>

(1)

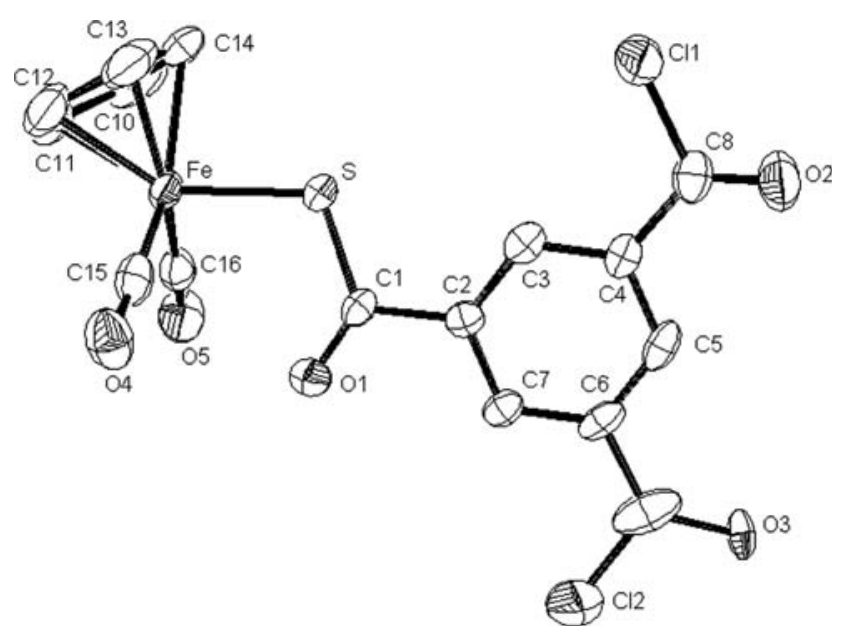

Fig. 1 ORTEP drawing of $\mathrm{CpFe}(\mathrm{CO})_{2} \mathrm{SCO}-3,5-\mathrm{C}_{6} \mathrm{H}_{3}(\mathrm{COCl})_{2}(\mathbf{1})$ at $30 \%$ probability

thiocarboxylate ligand $(1.216(2) \AA)$ are very comparable to those found in thiocarboxylate complexes $[9,10]$. The corresponding bond lengths of the free acid chloride groups are somewhat different from each other (1.391(8), 1.181(7)). This might be due to some disorder of one of these groups. The angles around the iron center ( $\mathrm{S}-\mathrm{Fe}-\mathrm{C} 15, \mathrm{~S}-\mathrm{Fe}-\mathrm{C} 16)$, $\mathrm{C} 16-\mathrm{Fe}-\mathrm{C} 15)$ are around $90^{\circ}$, consistent with a pseudooctahedral structure. The sulfur atom in this complex has a $\mathrm{sp}^{3}$ hybridization as predicted from the $\mathrm{Fe}-\mathrm{S}-\mathrm{C} 1$ angle.

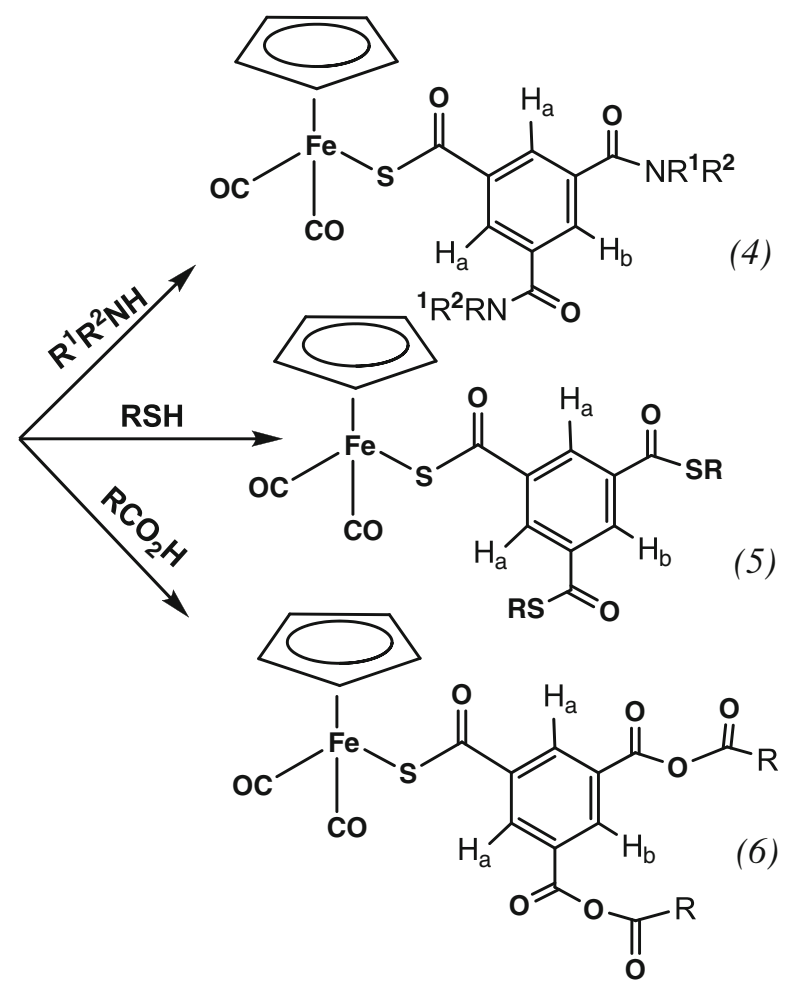

Table 1 Selected bond length $(\AA)$ and angles $\left(^{\circ}\right)$ of $\mathrm{CpFe}(\mathrm{CO})_{2} \mathrm{SCO}-$ $3,5-\mathrm{C}_{6} \mathrm{H}_{3}(\mathrm{COCl})_{2}(\mathbf{1})$

\begin{tabular}{lllc}
\hline $\mathrm{Fe}-\mathrm{S}$ & $2.2529(14)$ & $\mathrm{C} 1-\mathrm{S}-\mathrm{Fe}$ & $109.89(18)$ \\
$\mathrm{Fe}-\mathrm{C} 15$ & $1.764(7)$ & $\mathrm{C} 15-\mathrm{Fe}-\mathrm{S}$ & $93.94(18)$ \\
$\mathrm{Fe}-\mathrm{C} 16$ & $1.786(6)$ & $\mathrm{C} 16-\mathrm{Fe}-\mathrm{S}$ & $94.92(5)$ \\
$\mathrm{Fe}-\mathrm{C} 10$ & $2.093(6)$ & $\mathrm{C} 15-\mathrm{Fe}-\mathrm{C} 16$ & $94.42(3)$ \\
$\mathrm{Fe}-\mathrm{C} 11$ & $2.096(6)$ & $\mathrm{C} 8-\mathrm{O} 3-\mathrm{C} 9$ & $120.75(12)$ \\
$\mathrm{Fe}-\mathrm{C} 12$ & $2.091(6)$ & $\mathrm{C} 2-\mathrm{C} 1-\mathrm{S}$ & $114.6(4)$ \\
$\mathrm{Fe}-\mathrm{C} 13$ & $2.093(6)$ & $\mathrm{O} 1-\mathrm{C} 1-\mathrm{S}$ & $125.5(4)$ \\
$\mathrm{Fe}-\mathrm{C} 14$ & $2.091(6)$ & $\mathrm{O} 3-\mathrm{C} 9-\mathrm{C} 6$ & $129.8(6)$ \\
$\mathrm{S} 1-\mathrm{C} 1$ & $1.731(5)$ & $\mathrm{O} 3-\mathrm{C} 9-\mathrm{C} 2$ & $114.3(4)$ \\
$\mathrm{C} 1-\mathrm{O} 1$ & $1.216(6)$ & $\mathrm{C} 6-\mathrm{C} 9-\mathrm{Cl} 2$ & $115.7(5)$ \\
$\mathrm{C} 8-\mathrm{O} 2$ & $1.181(7)$ & $\mathrm{O} 2-\mathrm{C} 8-\mathrm{Cl} 1$ & $118.0(5)$ \\
$\mathrm{C} 9-\mathrm{O} 3$ & $1.391(8)$ & $\mathrm{O} 2-\mathrm{C} 8-\mathrm{Cl} 1$ & $126.9(5)$ \\
$\mathrm{C} 15-\mathrm{O} 4$ & $1.153(7)$ & $\mathrm{C} 4-\mathrm{C} 8-\mathrm{Cl1}$ & $115.1(4)$ \\
$\mathrm{C} 16-\mathrm{O} 5$ & $1.148(7)$ & & \\
\hline
\end{tabular}

Crystallographic data have been deposited with the Cambridge Crystallographic Data Centre, CCDC No. 711242.

Acknowledgments The financial support (grant no. 42/2007) from the Deanship of Scientific Research, Jordan University of Science and Technology is gratefully acknowledged. ME thanks Alexander von Humboldt foundation for equipment donation.

Open Access This article is distributed under the terms of the Creative Commons Attribution Noncommercial License which permits any noncommercial use, distribution, and reproduction in any medium, provided the original author(s) and source are credited. 


\section{References}

1. Patai S, Rappoport Z (eds) (1986/1987) The chemistry of organic selenium and tellurium compounds, vols 1 and 2. Wiley, New York

2. Murray SG, Hartley FR (1981) Chem Rev 81:365

3. Gysling HJ (1982) Coord Chem Rev 42:133

4. Ng MT, Vittal JJ (2006) Inorg Chem 45:10247

5. Jacob JH, Khalil AM, Muslat AO (2004) J Carcinog 3:1477

6. Muslat AO, Jibril I, Abussaud M, Abd-Alhadi E, Hamadeh Z (2002) J Appl Organomet Chem 16:44

7. Delgado JE, Donnadieu B, Hernandez E, Zamora PF (2004) J Organomet Chem 689:552

8. El-Hinnawi MA, Aruffo AA, Santarsiero BD, McAlister DR, Shomaker V (1983) Inorg Chem 22:1585

9. El-Hinnawi MA, Ajlouni A (1987) J Organomet Chem 332:321

10. El-Hinnawi MA, Ajlouni A, Abu-Nasser JS, Powell AK, Wahrenkamp H (1989) J Organomet Chem 359:79
11. El-khateeb M, Obidate T (2001) Polyhedron 20:2393

12. El-khateeb M, Asali KJ, Lataifeh A (2003) Polyhedron 22:3105

13. El-khateeb M, Asali KJ, Lataifeh A (2006) Polyhedron 25:1605

14. El-khateeb M, Roller A (2007) Polyhedron 26:3920

15. El-khateeb M, Goerls H, Weigand W (2006) Inorg Chim Acta 360:705

16. Jibril I, Ali AK (1997) Indian J Chem 36A:987

17. Jibril I, Ali AK, Omar JT (1997) Polyhedron 16:3327

18. Jibril I, Abd-Alhadi EH (2000) Indian J Chem 39A:1055

19. Jibril I, Abd-Alhadi EH, Hamadeh Z (2000) Trans Met Chem 25: 407

20. Sheldrick GM (1997) SHELXS-97, program for the solution of crystal structures. University of Göttingen, Germany

21. Sheldrick GM (1996) SHELXL-96, program for the refinment of crystal structures. University of Göttingen, Germany 